\title{
Idiopathic thrombocytopenic purpura (ITP) - new era for an old disease
}

\author{
MINODORA ONISÂI ${ }^{1,2}$, ANA-MARIA VLĂDĂREANU ${ }^{1,2}$, ANDREEA SPÎNU ${ }^{1}$, MIHAELA GĂMAN ${ }^{1,2}$, HORIA BUMBEA ${ }^{1,2}$ \\ ${ }^{1}$ Hematology Clinic, Emergency University Hospital, Bucharest, Romania \\ ${ }^{2}$ Carol Davila University of Medicine and Pharmacy, Bucharest, Romania
}

\begin{abstract}
Immune thrombocytopenia is an autoimmune hematological disorder characterized by severely decreased platelet count of peripheral cause: platelet destruction via antiplatelet antibodies which may also affect marrow megakaryocytes. Patients may present in critical situations, with cutaneous and/or mucous bleeding and possibly life-threatening organ hemorrhages (cerebral, digestive, etc.) Therefore, rapid diagnosis and therapeutic intervention are mandatory.

Corticotherapy represents the first treatment option, but as in any autoimmune disorder, there is a high risk of relapse. Second line therapy options include: intravenous immunoglobulins, thrombopoietin receptor agonists, rituximab or immunosuppression, but their benefit is usually temporary. Moreover, the disease generally affects young people who need repeated and prolonged treatment and hospitalization and therefore, it is preferred to choose a long term effect therapy. Splenectomy - removal of the site of platelet destruction - represents an effective and stable treatment, with $70-80 \%$ response rate and low complications incidence.

A challenging situation is the association of ITP with pregnancy, which further increases the risk due to the immunodeficiency of pregnancy, major dangers of bleeding, vital risks for mother and fetus, potential risks of medication, necessity of prompt intervention in the setting of specific obstetrical situations - delivery, pregnancy loss, obstetrical complications, etc.

We present an updated review of the current clinical and laboratory data, as well as a detailed analysis of the available therapeutic options with their benefits and risks, and also particular associations (pregnancy, relapsed and refractory disease, emergency treatment).
\end{abstract}

Key words: ITP, physiopathology, diagnosis, treatment, pregnancy.

\section{INTRODUCTION}

Immune thrombocytopenia - primary immune thrombocytopenic purpura (ITP) is defined as an isolated thrombocytopenia, without changes of the bone marrow and in the absence of other causes of thrombocytopenia [1]. The main characteristic of this pathology is increased peripheral destruction of platelets, the majority of patients showing antiplatelet membrane glycoproteins antibodies. The most severe complication is hemorrhage, the intracranial one presenting the highest risk. Mortality by hemorrhage is $1 \%$ in children and $5 \%$ in adults. In the case of adults with ITP, there is a major risk of severe hemorrhage in the elderly patients and with history of hemorrhage [2].

Primary ITP is characterized by isolated thrombocytopenia, as opposed to ITP secondary to other disorders, such as: autoimmune pathology (e.g. systemic lupus erythematosus), viral infections (chronic hepatitis $\mathrm{C}$ virus), lymphoproliferative neoplasms, etc.

The term of acute ITP, recently replaced by newly diagnosed ITP, has less than 3 months from diagnosis. Persistent ITP refers to immune thrombocytopenia with 3 months to 1 -year evolution, whereas chronic ITP is the disease longer than 12 months. Refractory ITP comprises cases which did not respond to splenectomy or relapsed after surgery, with high risk of bleeding, which makes it necessary to continue therapy [3].

\section{ETIOPATHOGENESIS}

As stated before, thrombocytopenia may be primary or secondary to an immune or infectious process [4-7]. The loss of tolerance to the glycoproteins expressed on the platelet or megakaryocyte surface is in fact the ITP pathogenic mechanism [6-13].

Classification of the immune tolerance disorders within ITP:

- disorders of peripheral immune tolerance arising in the setting of immune stimulation

- differentiation lines with denatured B lymphocytes subsets

- disorders of central immune tolerance during maturation or at the bone marrow level [6]. 
If the pathogenic mechanism is based on peripheral destruction, the response to therapy is good and post-treatment relapse rate is low. In this case, only platelets are affected. If there is also a production shortage (antibodies affecting megakaryocytes as well), the patients have a higher risk of relapse [3].

\section{- Secondary ITP}

The pathogenic mechanism of ITP in children is increased peripheral destruction of platelets; in two thirds of cases, the onset of the disease is preceded by an infectious episode; in $80 \%$ of patients there is spontaneous remission $[14,15]$. ITP secondary to infectious exposure or vaccines is another example of ITP with pathogenic mechanism of peripheral platelet destruction. Helicobacter pylori, varicella-zoster or cytomegalovirus infections may induce ITP. Incidence of ITP secondary to MMR vaccine is 1 in 40,000 administrations [16]. About $20 \%$ of the patients with ITP have chronic infection with hepatitis $\mathrm{C}$ virus (HCV), this being the most frequent ITP-associated infection [17].

The pathogenic mechanism of $\mathrm{HCV}$-associated ITP involves the activation of B-lymphocytes with production of anti $\mathrm{HCV}$ antibodies which crossinteract also with GP IIIa [18]. A similar mechanism is incriminated in thrombocytopenia related to HIV-infection, along with a direct inhibition of platelet production via HIV-infection of the megakaryocytes [19] and increased-platelet destruction by reactive oxygen species [20]. The risk of thrombocytopenia in HIV-infected patients is directly proportional with disease progression and inversely proportional with the response to antiretroviral treatment [3].

Studies reported that eradication of Helicobacter pylori infection was associated with resolution of otherwise "typical" ITP, especially for patients presenting with only mild thrombocytopenia. There are many theories suggested for $H$ pylori associated thrombocytopenia, but most of those discuss mimicry and cross-reactivity of the antibodies [7].

Chronic lymphocytic leukemia can associate ITP, with a prevalence of $1-5 \%$ [21]. The pathogenic mechanism is the differentiation blockage with the emergence of abnormal B cells. The low survival rate and the negative prognosis markers are common elements of this association. Although very rare (less than $1 \%$ of the cases), ITP can also occur in hematological diseases such as nonHodgkin lymphoma or Hodgkin disease. The pathogenic mechanism associated with secondary ITP in lymphoproliferative syndromes is platelet production shortage. A disorder of $\mathrm{B}$ and $\mathrm{T}$ lymphocytes apoptosis associated with mutations of the genes encoding Fas, Fas-L or other apoptosis mediators (caspases) is the mechanism underlying the autoimmune lympho-proliferative syndromes [22]. About $20 \%$ of the patients develop immune thrombocytopenia; additionally, neutropenia and/or autoimmune hemolytic anemia can occur. Association between autoimmune hemolytic anemia and immune thrombocytopenia is defined as Evans syndrome [23].

One third of the patients diagnosed with antiphospholipid syndrome can also present immune thrombocytopenia. The direct role of antiphospholipid antibodies in thrombocytopenia is unclear, since also anti-GP IIIa antibodies were found in thrombocytopenic patients with antiphospholipid syndrome [3].

Systemic lupus erythematosus (SLE) is another pathology associated with immune thrombocytopenia. Sustained response to corticotherapy in patients presenting both SLE and immune thrombocytopenia is lower compared to the response observed in primary thrombocytopenia, because most patients with secondary thrombocytopenia require also additional therapy with danazol or hydroxychloroquine in order to achieve a higher response rate [24].

Another situation of thrombocytopenia caused by production shortage is in the post-transplant settings, one of the mechanisms involved hereby being the alloantibodies production to the donor's platelets.

\section{- Primary ITP}

Typically, primary ITP has a CD4 + Th0/Th1 cytokine profile $[9,25]$. The levels of interferon gamma and interleukin-2 are high, and the number of regulatory $\mathrm{T}$ and $\mathrm{Th} 2^{+}$cells is lower in the peripheral blood [26]. Platelet count correlates inversely to the increased Th1/Th2 ratio. In ITP patients, the alteration of the regulatory factors of $\mathrm{T}$-cells apoptosis level adjusts the expression of $\mathrm{T}$ cells subsets and triggers the survival of $\mathrm{T}$ cell selfreactive clones [27]. Following splenectomy or Rituximab therapy, the Th1/Th2 ratio decreases, and the $\mathrm{V} \beta$ domain of T-lymphocytes becomes normal [13]. Additionally, if there is a response to Rituximab therapy or to thrombopoietic agents, a normal value of the regulatory $\mathrm{T}$ cells will be noticed; this response suggests a complex mechanism of Rituximab action (better than B CD20+ cell depletion) $[28,29]$. In ITP, the somatic mutations as well as the B-cell dependent and antigen-induced clonal expansion are the autoantibodies production triggers [30].

CD8+ cytotoxic T-lymphocytes cause platelet lysis using $\mathrm{A} / \mathrm{B}$, Apol and perphorine granzymes 
expressed on their surface [31]. ITP patients show an increased number of $\mathrm{VLA} 4^{+} \mathrm{CD} 3^{+} \mathrm{CD} 8^{+} \mathrm{T}$-cells in their bone marrow, which express the $\mathrm{CX} 3 \mathrm{Cr} 1^{+}$ receptor [32].

\section{- Antiplatelet antibodies}

The studies performed in the 70's showed an increased level of the platelet-associated IgG immunoglobulin in ITP patients [3]; further studies have shown that this was related to platelet $\alpha$ granules and was not specifically linked to platelet surface. The development of the test for detecting antigen-specific antiplatelet antibodies in the 80's led to the identification in $60 \%$ of the ITP patients of IgG reacting to the platelet membrane glycoproteins, mainly GPIIbIIIa ( $\alpha \mathrm{IIb} \beta 3$ integrine) and GP Ib/IX $[11,33]$. The antiplatelet antibodies are initially directed against a single glycoprotein on the platelet surface. Further on, by assimilating the platelets on whose surface antibodies are found and by processing the antigenic peptides in the platelet membrane of the glycoprotein structure which are not targeted by the antibodies, the antibody production against these new glycoproteins can be a result of epitope dissemination [34].

\section{- The antibody-dependent mechanism of platelet destruction}

In ITP patients, the platelet life span is short; a high percentage of platelets are destroyed in the spleen and liver [3]. Splenic macrophages phagocytize the platelets with antibodies attached to their membrane by means of the Fc $\gamma$ receptor [12]. The polymorphism of the gene which encodes Fc $\gamma$ RIII (FcrRIIIA - 581 V/V), a subtype of the Fc $\gamma$ receptor, is overexpressed; the $\mathrm{V} / \mathrm{V}$ isoform of the $\mathrm{Fc} \gamma$ receptor has increased affinity for the IgG1 and IgG3 immunoglobulins, as compared to the $\mathrm{F} / \mathrm{V}$ or $\mathrm{F} / \mathrm{F}$ isoforms. A monoclonal antibody of the FcyRIII $(\mathrm{mAb} 3 \mathrm{G} 8)$ receptor is able to increase the platelet value in patients with refractory ITP [3].

The existence of alternative mechanisms of platelet destruction, alongside with the primary mechanism of intrasplenic destruction, is reflected by the post-splenectomy relapse in one third of the patients [13]. In over one half of a cohort of 240 patients, the antiplatelet antibodies fixed the complement at the platelet membrane level, some of them inducing in vitro complement-dependent platelet lysis [35]. In HIV infected patients, amino acids 49-66 of antiGPIIIa antibodies induce total complement-independent destruction of platelets; in this process, peroxides of NADH/NADPH system are involved [20].

\section{CLINICAL DIAGNOSIS OF PRIMARY ITP}

The clinical features are correlated to the platelet number. Platelet counts below 20,000/ $\mu$ increase the risk of spontaneous bleeding like epistaxis or gum hemorrhage and menorrhagia, petechiae or ecchymoses, especially at the extremities [2,3]. Mucosal spontaneous bleeding may occur under $10,000 / \mu \mathrm{l}$; the bleeding time also increases. In extreme cases, when platelet number is below 5,000/ $\mu$, ITP patients may present severe hemorrhagic complications (subarachnoid, intracerebral hemorrhage, digestive hemorrhage or other internal bleedings $[2,3,7]$.

Signs and symptoms associated with secondary ITP to different disorders are:

- rash, arthralgia, serositis - suggesting SLE;

- hepatomegaly and elevated transaminase values - associated to virus $C$ hepatitis;

- fever and lymphadenopathies - associated to infections or lymphoproliferative neoplasms.

Hemorrhages involving the skin, mucosae, gastrointestinal tract or any other organ are the most frequent clinical trait in ITP patients. The "dry purpura" usually occurs in absence of a preceding event. The mucosal hemorrhage may manifest as epistaxis, menorrhagia, gum bleeding and digestive hemorrhage [36]. Patients with severe thrombocytopenia present oral hemorrhagic lesions; additionally, they may have severe hemorrhagic manifestations without any clinical expression.

The most severe complication of ITP, more frequent in adults than in children, occurring at a platelet count lower than $10,000 / \mu 1$, is the intracranial hemorrhage [15, 37, 38].

There is a higher risk of hematological neoplasms in ITP patients, with a 5-year cumulative risk of 4.7 (95\% CI, 1.7-12.7) for hematologic malignancies determined on a Danish populationbased cohort study of 407 primary chronic ITP patients [39]. A high occurrence of CLL phenotype lymphocytes was demonstrated [40].

The overall incidence of hemorrhagic events was $3.2 \%$ per patient per year, in a study conducted by Cortelazzo. Although the patients had similar platelet counts, $10.4 \%$ of the patients over the age of 60 presented hemorrhagic events, as compared to the $0.4 \%$ of the patients under 40 . A previous history of hemorrhage predicted an increased risk of bleeding with a relative risk of $27.5[2,3]$.

Studies did not demonstrate a direct correlation between the severity of bleeding and the platelet count. This hypothesis might be explained by binding of antiplatelet antibodies to highly restrictive areas of the $\beta$-helix of GP IIb domain, near fibrinogen 
ligand site, a process which can interfere with platelet aggregation.

Fatigability occurs in $22 \%$ of children and $22-39 \%$ of adults [41]. Treatment response correlates with the significant improvement of fatigue and other parameters quantifying health-related quality of life measurements [42]. A study performed by Mathias (2007) demonstrated that fatigability occurs in patients with platelets under $10.000 / \mu 1$, with ongoing hemorrhages and during corticotherapy; on the other hand, there is no connection between fatigability and ITP duration, patient age or gender [43]. In ITP patients, fatigability can result from a high level of inflammatory cytokines, particularly IL-2 and IFN- $\gamma$, associated with the Th1 profile.

Thrombosis - recent studies show that ITP patients have a high thrombosis risk. Aledort reported 18 thromboembolic accidents in 186 adult ITP patients [44]. The severity of thrombocytopenia correlates with the thrombosis development risk.

The mechanism is unclear - an explanation of this process could be the occurrence of antiphospholipid antibodies in these patients, which increase the risk of thrombosis onset [45]. Although the guidelines do not recommend in ITP patients routine screening for antiphospholipid antibodies [46, 47], the latter should be considered in patients who develop thrombosis. Other factors involved in the pathogenesis of thrombosis are the increased level of prothrombotic microparticles derived from platelets and the activation of the complement on the platelet surface covered by antibodies [48].

The guidelines do not discuss the management of thrombosis in thrombocytopenic patients with ITP. Experts consider that for a platelet count over $40,000 / \mu 1$, anticoagulant treatment can be used, but the decision depends on the severity of thrombosis and the patient's characteristics. During anticoagulant therapy, concomitant aggressive treatment for ITP is mandatory.

\section{LABORATORY DIAGNOSIS}

ITP is defined by isolated thrombocytopenia, with normal morphology and otherwise normal CBC. If present, abnormal platelet morphology should result in a diagnosis of an inherited platelet disorder, such as macrothrombocytopenia in the presence of the MYH9 mutation [49]. A careful examination of the peripheral blood smear (PBS) is necessary to exclude other causes of thrombocytopenia, such as the microangiopathic disorders, platelet satellitism or pseudothrombocytopenia. Sometimes, isolated thrombocytopenia can be identified in acute or chronic leukemia, myelodysplastic syndromes, but in such settings, CBC and PBS reveal different other alterations suggestive for the underling hematological disorder. A 2011 report shows a decrease of platelet precursors in ITP patients; Eltrombopag increases the number of platelet precursors [50].

In ITP patients, a normal or increased number of megakaryocytes can be present in the bone marrow, sometimes with an increased number of immature megakaryocytes. The ultrastructural analysis can reveal the megakaryocyte apoptosis [51].

Bone marrow examination is not usually mandatory in ITP. It is recommended to be performed if another hematological pathology is suspected (other anomalies on the CBC, unexpected systemic signs and symptoms, such as adenopathies, organ enlargement, etc), if patients are over 60 years old, and before splenectomy [47].

For the diagnosis of ITP, the sensitivity of antiplatelet IgG-antibody testing is $91 \%$, although the specificity is only $27 \%$; therefore, the positive predictive value is only $48 \%$ and the diagnostic value is low. The lack of utility of antiplatelet antibody testing has been illustrated by several studies. For this reason and the lack of correlations with clinical outcomes, the test is not routinely recommended in the diagnosis or management of ITP $[34,52]$.

The ITP international working group guidelines recommend the following lab tests: the reticulocyte count and the Coombs tests to rule out autoimmune hemolytic anemia, blood group and Rh type - useful for therapeutic purposes [anti-Rh(D) therapy], screening for HIV, C hepatitis (viral infections that often cause thrombocytopenia, in some cases as a form of secondary ITP) and Helicobacter pylori, as stated before, due to the association between thrombocytopenia and $H$. pylori infection, especially found in some geographical regions [7, 47].

\section{DIFFERENTIAL DIAGNOSIS}

Diagnosis of primary ITP is an exclusion one, considering the non-immune causes of thrombocytopenia and secondary immune thrombocytopenia. Druginduced immune thrombocytopenia (DITP) is induced and/or perpetuated by the presence of a drug or other ingested substance (eg, quinine, quinine-containing beverages, some antibiotics such as Vancomycin or trimethoprim-sulfamethoxazole, heparin, Valproic acid, etc) and is expected to resolve after drug 
discontinuation [3]. The thrombocytopenia of nonimmune etiology includes drug or toxin administration (eg. alcohol, chemotherapy - which inhibit platelet production), platelet splenic sequestration, primary disorders of the bone marrow, prior radiation exposure (therapeutic or accidental) and hereditary thrombocytopenias.

Hereditary thrombocytopenias can be misdiagnosed as ITP [53]. There is diagnostic suspicion when there is a family history of thrombocytopenia or there is no response to standard therapy. The family history of thrombocytopenia is supported in some cases by the absence of the radius syndrome (the TAR syndrome), anomalies in the right cavities of the heart (the di George syndrome) or platelets increased in size and Döhle bodies in neutrophils (gene MYH9-connected anomalies) [54].

Bernard-Soulier syndrome is an autosomal recessive familial thrombocytopenia, characterized by the absence of the GPIb-IX platelet complex with large platelets, with decreased platelet aggregation at increased doses of ristocetine and hemorrhages [55].

Wiskott-Aldrich syndrome is an X-linked syndrome, characterized by severe immunodeficiency and small size platelets. Congenital amegakayriocytic thrombocytopenia is a recessive autosomal disorder, caused by the mutations at c-Mpl gene which further cause the absence of megakaryocytes accompanied by severe thrombocytopenia.

The pathology of hereditary thrombocytopenias is represented by mutations at the transcription factors - such as GATA1 (sex-connected heredity) and RUNX1 (dominant autosomal) - with abnormal megakaryocyte maturation.

\section{THERAPEUTIC OPTIONS IN ITP}

As compared to the general population, the morbidity and mortality rate in ITP patients is higher, especially if under treatment the platelet count is lower than $30,000 / \mu 1[39,56]$. Mortality is equally influenced by hemorrhage and infections [56].

As the majority of cases evolve to chronic disease and the hemorrhage risk is higher than in children, the ITP management in adults is more complex [36, 39]. The therapeutic objective is to achieve a hemorrhage risk-free platelet count,

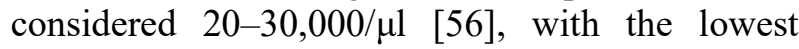
toxicity of medication. For a platelet count above $50,000 / \mu 1$, treatment in unnecessary, the indication being set according to the individual hemorrhage risk, age, patient's life style and option.

\section{- First-line treatment}

Corticosteroids are the most widely used treatment. Initially, at least $80 \%$ of the ITP patients respond; a high percentage of patients relapse when attempting to reduce the corticosteroid doses $[47,57]$. Studies have been conducted to analyze if in the newly diagnosed ITP patients, an increased dose of corticosteroids results in a longer remission. The results of Cheng's study reveal a sustained response - a platelet value over $50,000 / \mu \mathrm{l}$ - maintained 6 months later in $50 \%$ of the patients treated with $40 \mathrm{mg}$ of dexamethasone per day for 4 days [58]. Mazzucconi's study noticed a 15-month survival rate with no relapse in newly diagnosed patients treated with 4-6 cycles of dexamethasone, administered every two weeks [57]. A comparative study by Zaja showed the superiority of associating dexamethasone and Rituximab against the single-drug therapy with dexamethasone as first line treatment, leading to better response in 6 months; for a longer monitoring period, these differences become unremarkable [59].

Increased dose dexamethasone has similar effects to the standard dose of prednisolone, as demonstrated by a 2010 prospective multicentric study [60].

Intravenous immunoglobulins (IVIg) are often administered in association with corticotherapy, particularly when it is necessary to raise the platelet count in a short time. Another indication is the use in order to preserve a risk-free platelet count in patients with thrombocytopenia after reduction of corticosteroid doses, until a more permanent therapeutic solution is applied. In $60-80 \%$ of the patients, IVIg increase the platelet count, sometimes within days, but the response is short (1 to 3 weeks); the therapy is efficient both in splenectomized and in non-splenectomized patients. Although multiple regimens have been suggested, clinicians prefer the dose of $1 \mathrm{~g} / \mathrm{kg} /$ day, administered intravenously for 1-2 days [13]. The mechanisms of action of IVIg include: inhibition of megakaryocyte apoptosis and activation of cytotoxic T-cells, modulation of cytokines and the expression and activity of the Fc $\gamma$ receptor, and neutralization of the complement [61, 62]. Adverse reactions include aseptic meningitis, edema, nephrotoxicity, thrombosis and rarely severe hemolytic anemia.

Anti-Rh(D) antibody links to the $\mathrm{Rh}(\mathrm{D})$ antigen on the erythrocyte membrane, thus inducing clearance of the cells with antibodies on their surface and inhibition of the opsonized platelet clearance by the reticulo-endotelial system [62]; other mechanisms involved include Fc $\gamma$ receptor and inflammatory cytokine modulation and reduction of the antigens 
specific for the B-lymphocyte membrane. The Anti-D therapy is efficient only in patients with intact spleen function and $\mathrm{Rh}(\mathrm{D})$ positive. The hemolysis determined by Anti-D is reflected in the decrease by $0.5-2 \mathrm{~g} / \mathrm{dl}$ of the hemoglobin value; about 1 patient in 1,000 may suffer severe hemolysis, rarely associated with disseminated intravascular coagulation features, kidney failure and exitus [63]. Response is achieved in $70 \%$ of the patients treated with the approved dose of $50 \mu \mathrm{g} / \mathrm{kg}$; a higher dose $(75 \mu \mathrm{g} / \mathrm{kg})$ correlates with a higher response rate. Cooper et al. showed that repeated immunoglobulin administration for recurrent thrombocytopenia has a long-term result in $43 \%$ of patients [64].

\section{Second-line therapy}

For ITP resistant to corticotherapy, IVIg or anti-D Ig, there are some secondary therapy lines. As compared to the older agents, Rituximab and the thrombopoietin receptor agonists have increased efficacy with minor adverse reactions $[65,66]$.

Rituximab is a chimeric antiCD20 antibody frequently used as a secondary treatment line. It induces long-term response in about $21 \%$ of adults [67]. The recommended dose is $375 \mathrm{mg} / \mathrm{m}^{2}$ weekly for 4 weeks, although a dose of $100 \mathrm{mg} / \mathrm{m}^{2}$ has similar efficiency [68]. The mechanism of action involves a complex immunological modulation. The success of the treatment was correlated in one study with the normalization of T-lymphocyte distribution [69] and in another with a normal value and function of the regulatory T-lymphocytes [29]. The adverse reactions of Rituximab include immediate infusionrelated reactions, vasculitis, and cardiac rhythm disorders.

Splenectomy is the treatment method which offers the most long-term remission, considered the "gold standard" [70]. It was the first successful method in the ITP treatment. According to a systematic review which included 135 cases, 66\% of the patients fully responded to splenectomy [87]. Another systematic review including 1223 patients with ITP treated by laparoscopic splenectomy reveals a $72 \%$ 5-year success rate; most relapses occur during the first two years post-splenectomy [71].

Splenectomy has been associated with a high risk of infections and post-surgery sepsis. It is not certain yet if the splenectomized ITP patients have a high risk for infection post-splenectomy as compared to other ITP patients who have not undergone surgery. A Danish study reports that - as compared to the non-splenectomized patients but recommended for surgery (ITP) - in the splenectomized patients for ITP the infection was seen only within the first
90 days post-surgery. Afterwards there was no such infectious risk, with a relative risk of 1 between days 91 and 365 and 1.4 over 1 year post-splenectomy. Enterobacterias are the etiology of early infections [72]. Despite this, the morbidity connected to longterm infections and the post-splenectomy morbidity can be considerably reduced by encapsulated antimicroorganism immunization and the aggressive treatment of the fever syndrome.

The place of splenectomy within the ITP management is different according to present day guidelines. The International Working Group [47] as well as the American Society of Hematology guidelines [46] classify it among the second-line treatment options, recommending it for cases resistant to corticotherapy; Rituximab and thrombopoietic agents are considered alternative second-line methods. In clinical practice, the therapeutic decision is particularized on a case by case situation [73].

Thrombopoietin receptor agonists (TRA) Some clinicians keep this type of treatment strictly for the refractory ITP patients; in contrast, other doctors recommend them in newly diagnosed cases, with the aim of supporting the platelet count during the first year of diagnosis, hoping to attain spontaneous hematological remission [74]. None of the two approved TRAs (Romiplostin and Eltrombopag) is homologous to the thrombopoietin structure. By linking to the thrombopoietin receptor $\mathrm{c}-\mathrm{Mpl}$ on the megakaryocytes, both drugs stimulate the differentiation and proliferation of the megakaryocytes and thereby increase the platelet production [75].

Romiplostim (Nplate) is a fusion protein containing four thrombopoietin peptodomimetic regions, linked to an $\mathrm{Fc}$ domain ensuring in vivo stability [76]. The dose is dictated by the platelet count; it is administered subcutaneously, weekly. The efficacy of this drug was assessed in two placebo-controlled phase III trials, which enrolled 63 splenectomized patients and 62 non-splenectomized patients, respectively, the latter being diagnosed with severe chronic ITP [77]. In $38 \%$ of the splenectomized patients (as compared to $0 \%$ in the placebo group) and in $61 \%$ of the non-splenectomized ones (as compared to $5 \%$ of the placebo group) who had received Romiplostim, there was a longterm response, defined by a platelet value higher than $50,000 / \mu 1$, preserved 6 of the last 8 treatment weeks. The patients treated with Romiplostim were more susceptible to reduce or interrupt treatment (corticotherapy) and very few salvage treatment [77].

Eltrombopag is a small molecule whose action mechanism is similar to that of Romiplostim, although 
Eltrombopag links to the transmembrane region of c-Mpl and not to the link site of the ligand (thrombopoietin) [78]. After the phase I trials, the drug was tested on patients with severe chronic ITP at 6-week and 6-month intervals, respectively [79]; $59-79 \%$ of the patients treated with the pharmacoactive product (as compared to $16-28 \%$ of the patients treated with placebo) responded; similar responses were noticed in the splenectomized patients, as compared to the non-splenectomized ones. Also, the treated patients had fewer hemorrhagic episodes, and a higher percentage of them reduced the ITP associated medication. The EXTEND study analyzed the long-term safety and efficacy [80]: $88 \%$ of patients had a platelet count over $50,000 / \mu 1$ at least once during the study period; the value before treatment, the splenectomy history or the prior ITP medication were not predictive for the response.

Both TRAs are well tolerated, although some adverse reactions have been identified [81]. In $8-10 \%$ of patients who cease treatment, there is a thrombocytopenia rebound, which may cause consistent hemorrhage [81, 82]. Within the first two weeks after treatment cessation, careful monitoring of the platelet number is necessary. A higher platelet value, in response to the TRAs, correlates with arterial and venous thrombosis risk [83]. Two $(0.5 \%)$ of the 407 patients treated with Romiplostim suffered a cerebro-vascular accident, deep venous thrombosis or pulmonary embolism [84]; in contrast, in 19 of the 301 patients treated with Eltrombopag, a total of 25 thromboembolic events occurred [80]. There was no correlation between the platelet value and thrombosis in any of the studies. In about $5 \%$ of the patients treated with TRAs, a higher degree of reticulin fibrosis was noticed in the bone marrow [81]. In most cases, the process was not associated with clinical signs of bone marrow dysfunction [85].

In patients treated with TRAs, it is mandatory to monitor the platelet count and peripheral blood smear; the loss of response or the development of fibrosis impose cessation of the treatment.

\section{ITP AND PREGNANCY}

Antiplatelet autoantibodies have the ability to cross the fetoplacental barrier, as they are $\mathrm{IgG}$ type. Therefore, in pregnant ITP patients, antiplatelet autoantibodies can also destroy the fetus's platelets. Thus, ITP is the main etiology of the fetal or neonatal immune thrombocytopenia. As compared to the children diagnosed with neonatal alloimmune thrombocytopenia, about $10 \%$ of the newborn affected by ITP will have a platelet count below $50,000 / \mu 1$ and the risk of intracerebral hemorrhage will exist in $1-2 \%$ [3].

Although neonatal thrombocytopenia cannot be discovered by lab tests, risk factors should be taken into consideration. Splenectomy antecedents for the maternal ITP, an ITP sibling or gestational thrombocytopenia (platelet value lower than $100,000 / \mu \mathrm{l})$ will increase the risk of neonatal thrombocytopenia [3].

It is recommended to test for antiplatelet antibodies in ITP or thrombocytopenic patients. It is necessary to start the treatment - corticotherapy or immunoglobulins - in the case of symptomatic thrombocytopenia and presence of antiplatelet antibodies.

Because the thrombocytopenia secondary to maternal ITP has a lower risk than the neonatal autoimmune thrombocytopenia, the fetus's platelet value is not to be measured. During the newborn's first days of life, it is recommended to monitor the platelet value, though. According to the severity of thrombocytopenia, transfusions with platelet concentrates can be administered [3].

\section{EMERGENCY TREATMENT IN ITP}

Hospitalization is mandatory for patients with severe thrombocytopenia and especially for the newly diagnosed ones. The aim of therapy is to increase the platelet value as soon as possible. Corticotherapy or immunoglobulins are administered i.v., and in critical situations the number of platelets can be temporarily increased by platelet concentrate transfusions. In some patients, the life span of the transfused platelets can be raised by the simultaneous administration of immunoglobulins [86]. In order to increase the platelet number very rapidly, splenectomy may be used; it was performed as an ITP treatment method in patients with severe intracranial hemorrhage [3].

\section{- Refractory ITP}

The management of this form relies on chemotherapy and immunosuppressive agents, such as azathioprine, cyclophosphamide, vinca alcaloids, danazol, cyclosporine and mycophenolat mofetil [66].

Refractory ITP is diagnosed when the patient relapses or does not respond to splenectomy, and there is a severely decreased platelet count or active hemorrhage is present, requiring treatment. The last criterion does not include the treatment preceding an invasive procedure or the hemorrhage prophylaxis after major trauma. Refractory patients 
can get temporary response to i.v. corticosteroids or immunoglobulins. Literature highlights that in over $60 \%$ of the cases, splenectomy is curative; this result was not obtained by any of the other treatment methods [87, 88, 89]. In non-splenectomized ITP patients, refractory disease is out of the question. Keeping in mind the benign feature of the pathology in children and the postponement of splenectomy, criteria for refractory ITP in children have not been defined. ITP in non-splenectomized patients who do not respond to medication must be described as newly diagnosed ITP, persistent or chronic (in accordance with the duration of the disease), nonresponsive to one or more agents.

The main purpose of treatment in refractory ITP is achieving an optimal platelet value, in order to prevent significant hemorrhage, with minimum toxicity of the therapy $[90,91]$. In case of a severe hemorrhage, in any stage of the pathology, adjuvant treatment or even platelet transfusions are mandatory [27].

\section{CONCLUSIONS}

Immune thrombocytopenia is an autoimmune hematological disorder usually characterized by severely decreased platelet count of peripheral cause. Patients may present in critical situations, with cutaneous and/or mucous bleeding and possibly life-threatening organ hemorrhage (cerebral, digestive, etc.). Therefore, rapid diagnosis (considering multiple differential diagnoses) and therapeutic intervention is mandatory. First line treatment indications are quite clear, but most patients relapse and good knowledge of available options and their benefits is required.

Trombocitopenia imună reprezintă o patologie hematologică autoimună caracterizată prin scăderea marcată a numărului de trombocite de cauză perifericăa: distrucţie plachetară prin anticorpi antitrombocitari, care pot afecta de asemenea şi megakariocitele medulare. Pacienţii se pot prezenta în situatii critice, cu hemoragii cutanate şi/sau mucoase severe şi chiar cu hemoragii ameninţătoare de viaţă (cerebrală, digestivă etc.). Astfel, se impun diagnosticul şi intervenţia rapidă.

Corticoterapia reprezintă prima opţiune de tratament, dar, ca în orice patologie autoimună, exista un risc mare de recăderi. A doua linie de tratament este reprezentată de: imunoglobulinele intravenoase, agoniştii de receptori de trombopoietină, rituximab sau agenți imunosupresori, dar beneficiul acestora este de regulă temporar. In plus, boala afectează de regulă persoanele tinere care astfel necesită tratamente şi spitalizări repetate şi prelungite, astfel încât este de ajutor o opţiune terapeutică cu efect prelungit. Splenectomia - îndepărtarea situsului de distrucţie trombocitară - reprezintă un tratament eficient şi stabil, cu o rată de răspuns de 70-80\% ş̧i rată mică de complicaţii.

O situaţie particulară este trombocitopenia imună în sarcină, care asociază risc crescut şi prin imunodeficienţa specifică sarcinii, pericolele semnificative în cazul apariţiei hemoragiilor, riscurile vitale pentru mamă şi făt, riscurile potenţiale ale medicaţiei, necesitatea unei intervenţii rapide în anumite situaţii obstetricale specifice - naşterea, pierderea sarcinii, complicații obstetricale etc.

Prezentăm un review al datelor actuale clinice şi de laborator, al opțiunilor terapeutice disponibile din punct de vedere al riscurilor şi beneficiilor, precum şi câteva situaţii particulare - sarcina, boala refractară sau cu recădere, terapia în urgenţă.

Correspondence to: Mihaela Găman MD, PhD, University Assistant, Carol Davila University of Medicine and Pharmacy Hematology Clinic, Emergency University Hospital Bucharest, Romania

Tel: +40721262638

E-mail: dervesteanu_mihaela@yahoo.com

Conflict of interest disclosure: The authors declare that there are not conflicts of interest. 


\section{REFERENCES}

1. ONISÂI M, VLĂDĂREANU AM, DELCEA C, CIORĂSCU M, BUMBEA H, NICOLESCU A, et al. Perinatal outcome for pregnancies complicated with thrombocytopenia. J Matern Fetal Neonatal Med. 2012; 25(9):1622-6.

2. CORTELAZZO S1, FINAZZI G, BUELLI M, MOLTENI A, VIERO P, BARBUI T. High risk of severe bleeding in aged patients with chronic idiopathic thrombocytopenic purpura. Blood. 1991; 77(1):31-3.

3. KISTANGURI G, MCCRAE K. Immune Thrombocytopenia. Hematol Oncol Clin North Am. 2013; 27(3):495-520.

4. STASI R, NEWLAND AC. ITP: a historical perspective. Br J Haematol. 2011; 153(4):437-450.

5. COOPER N. State of the art - how I manage immune thrombocytopenia. Br J Haematol. 2017 Apr; 177(1):39-54.

6. CINES DB, BUSSEL JB, LIEBMAN HA, LUNING PRAK ET. The ITP syndrome: pathogenic and clinical diversity. Blood. 2009; 113:6511-21.

7. CINES DB, LIEBMAN H, STASI R. Pathobiology of secondary immune thrombocytopenia. Semin Hematol. 2009; 46:S2-14.

8. CUKER A, CINES DB. Immune thrombocytopenia. Hematology Am Soc Hematol Educ Program. 2010; 2010:377-84.

9. TOLTL LJ, NAZI I, JAFARI R, ARNOLD DM. Piecing together the humoral and cellular mechanisms of immune thrombocytopenia. Semin Thromb Hemost. 2011; 37(6):631-639.

10. SEMPLE JW, PROVAN D, GARVEY MB, FREEDMAN J. Recent progress in understanding the pathogenesis of immune thrombocytopenia. Curr Opin Hematol. 2010; 17(6):590-595.

11. MCMILLAN R. Antiplatelet antibodies in chronic immune thrombocytopenia and their role in platelet destruction and defective platelet production. Hematol Oncol Clin North Am. 2009; 23(6):1163-1175.

12. NUGENT D, MCMILLAN R, NICHOL JL, SLICHTER SJ. Pathogenesis of chronic immune thrombocytopenia: increased platelet destruction and/or decreased platelet production. Br J Haematol. 2009; 146(6):585-596.

13. STASI R. Immune thrombocytopenia: pathophysiologic and clinical update. Semin Thromb Hemost. 2012; 38(5):454-462.

14. BLANCHETTE V, BOLTON-MAGGS P. Childhood immune thrombocytopenic purpura: diagnosis and management. Hematol Oncol Clin North Am. 2010; 24(1):249-273.

15. BREAKEY VR, BLANCHETTE VS. Childhood immune thrombocytopenia: a changing therapeutic landscape. Semin Thromb Hemost. 2011; 37(7):745-755.

16. LIEBMAN HA. Viral-associated immune thrombocytopenic purpura. Hematology Am Soc Hematol Educ Program. 2008:212-218.

17. RAJAN SK, ESPINA BM, LIEBMAN HA. Hepatitis C virus-related thrombocytopenia: clinical and laboratory characteristics compared with chronic immune thrombocytopenic purpura. Br J Haematol. 2005; 129(6):818-824.

18. ZHANG W, NARDI MA, BORKOWSKY W, LI Z, KARPATKIN S. Role of molecular mimicry of hepatitis $C$ virus protein with platelet GPIIIa in hepatitis C-related immunologic thrombocytopenia. Blood. 2009; 113(17):4086-4093.

19. LI Z, NARDI MA, KARPATKIN S. Role of molecular mimicry to HIV-1 peptides in HIV-1 related immunologic thrombocytopenia. Blood. 2005; 106:572-576.

20. NARDI M, TOMLINSON S, GRECO MA, KARPATKIN S. Complement-independent, peroxide-induced antibody lysis of platelets in HIV-1-related immune thrombocytopenia. Cell. 2001; 106:551-561.

21. LIEBMAN HA. Recognizing and treating secondary immune thrombocytopenic purpura associated with lymphoproliferative disorders. Semin Hematol. 2009; 46(1 Suppl 2):S33-S36.

22. TEACHEY DT. New advances in the diagnosis and treatment of autoimmune lymphoproliferative syndrome. Curr Opin Pediatr. 2012; 24(1):1-8.

23. MICHEL M, CHANET V, DECHARTRES A, MORIN AS, PIETTE JC, CIRASINO L, et al. The spectrum of Evans syndrome in adults: new insight into the disease based on the analysis of 68 cases. Blood. 2009; 114(15):3167-3172.

24. ARNAL C, PIETTE JC, LEONE J, TAILLAN B, HACHULLA E, ROUDOT-THORAVAL F, et al. Treatment of severe immune thrombocytopenia associated with systemic lupus erythematosus: 59 cases. J Rheumatol. 2002; 29(1):75-83.

25. PANITSAS FP, THEODOROPOULOU M, KOURAKLIS A, KARAKANTZA M, THEODOROU GL, ZOUMBOS NC, et al. Adult chronic idiopathic thrombocytopenic purpura (ITP) is the manifestation of a type-1 polarized immune response. Blood. 2004; 103(7):2645-2647.

26. SAKAKURA M, WADA H, TAWARA I, NOBORI T, SUGIYAMA T, SAGAWA N, et al. Reduced CD4+CD25+T cells in patients with idiopathic thrombocytopenic purpura. Thromb Res. 2007; 120(2):187-193.

27. RODEGHIERO F, STASI R, GERNSHEIMER T, MICHEL M, PROVAN D, ARNOLD D, et al. Standardization of terminology, definitions and outcome criteria in immune thrombocytopenic purpura of adults and children: report from an international working group. Blood. 2009; 113(11):2386-93.

28. BAO W, BUSSEL JB, HECK S, HE W, KARPOFF M, BOULAD N, et al. Improved regulatory T-cell activity in patients with chronic immune thrombocytopenia treated with thrombopoietic agents. Blood. 2010; 116(22):4639-4645.

29. STASI R, COOPER N, DEL POETA G, STIPA E, LAURA EVANGELISTA M, ABRUZZESE E, et al. Analysis of regulatory $T$-cell changes in patients with idiopathic thrombocytopenic purpura receiving $B$ cell-depleting therapy with rituximab. Blood. 2008; 112(4):1147-1150.

30. ROARK JH, BUSSEL JB, CINES DB, SIEGEL DL. Genetic analysis of autoantibodies in idiopathic thrombocytopenic purpura reveals evidence of clonal expansion and somatic mutation. Blood. 2002; 100:1388-1398.

31. OLSSON B, ANDERSSON PO, JERNAS M, JACOBSSON S, CARLSSON B, CARLSSON LM, et al. T-cell-mediated cytotoxicity toward platelets in chronic idiopathic thrombocytopenic purpura. Nat Med. 2003; 9(9):1123-1124.

32. OLSSON B, RIDELL B, CARLSSON L, JACOBSSON S, WADENVIK H. Recruitment of T cells into bone marrow of ITP patients possibly due to elevated expression of VLA-4 and CX3CR1. Blood. 2008; 112(4):1078-1084.

33. MCMILLAN R. Antiplatelet antibodies in chronic adult immune thrombocytopenic purpura: Assays and epitopes. J Pediatr Hematol Oncol. 2003; 25:S57-S61.

34. CINES DB, BLANCHETTE VS. Immune thrombocytopenic purpura. N Engl J Med. 2002; 346:13-995. 
35. NAJAOUI A, BAKCHOUL T, STOY J, BEIN G, RUMMEL MJ, SANTOSO S, et al. Autoantibody-mediated complement activation on platelets is a common finding in patients with immune thrombocytopenic purpura (ITP). Eur J Haematol. 2012; 88(2):167-174.

36. NEYLON AJ, SAUNDERS PW, HOWARD MR, PROCTOR SJ, TAYLOR PR. On behalf of the Northern Region Haematology Group. Clinically significant newly presenting autoimmune thrombocytopenic purpura in adults: a prospective study of a population-based cohort of 245 patients. Brit J Haematol. 2003; 122:966-974.

37. PSAILA B, PETROVIC A, PAGE LK, MENELL J, SCHONHOLZ M, BUSSEL JB. Intracranial hemorrhage (ICH) in children with immune thrombocytopenia (ITP): study of 40 cases. Blood. 2009; 114(23):4777-4783.

38. KUHNE T, BERCHTOLD W, MICHAELS LA, WU R, DONATO H, ESPINA B, et al. Newly diagnosed immune thrombocytopenia in children and adults: a comparative prospective observational registry of the Intercontinental Cooperative Immune Thrombocytopenia Study Group. Haematologica. 2011; 96(12):1831-1837.

39. NORGAARD M, JENSEN AO, ENGEBJERG MC, FARKAS DK, THOMSEN RW, CHA S, et al. Long-term clinical outcomes of patients with primary chronic immune thrombocytopenia: a Danish population-based cohort study. Blood. 2011; 117(13): 3514-3520.

40. MITTAL S, BLAYLOCK MG, CULLIGAN DJ, BARKER RN, VICKERS MA. A high rate of CLL phenotype lymphocytes in autoimmune hemolytic anemia and immune thrombocytopenic purpura. Haematologica. 2008; 93(1):151-152.

41. NEWTON JL, REESE JA, WATSON SI, VESELY SK, BOLTON-MAGGS PH, GEORGE JN, ET AL. Fatigue in adult patients with primary immune thrombocytopenia. Eur J Haematol. 2011; 86(5):420-429.

42. KUTER DJ, MATHIAS SD, RUMMEL M, MANDANAS R, GIAGOUNIDIS AA, WANG X, et al. Health-related quality of life in nonsplenectomized immune thrombocytopenia patients receiving romiplostim or medical standard of care. Am J Hematol. 2012; 87(5):558-561.

43. MATHIAS SD, BUSSEL JB, GEORGE JN, MCMILLAN R, OKANO GJ, NICHOL JL. A disease-specific measure of healthrelated quality of life for use in adults with immune thrombocytopenic purpura: its development and validation. Health Qual Life Outcomes. 2007; 5:11.

44. ALEDORT LM, HAYWARD CP, CHEN MG, NICHOL JL, BUSSEL J. Prospective screening of 205 patients with ITP, including diagnosis, serological markers, and the relationship between platelet counts, endogenous thrombopoietin, and circulating antithrombopoietin antibodies. Am J Hematol. 2004; 76(3):205-213.

45. DIZ-KUCUKKAYA R, HACEHANEFIOGLU A, YENEREL M, TURGUT M, KESKIN H, NALÇACI M, et al. Antiphospholipid antibodies and antiphospholipid syndrome in patients presenting with immune thrombocytopenic purpura: a prospective cohort study. Blood. 2001; 98:1760-1764.

46. NEUNERT C, LIM W, CROWTHER M, COHEN A, SOLBERG L, JR, CROWTHER MA. The American Society of Hematology 2011 evidence-based practice guideline for immune thrombocytopenia. Blood. 2011; 117(16):4190-4207.

47. PROVAN D, STASI R, NEWLAND AC, BLANCHETTE VS, BOLTON-MAGGS P, BUSSEL JB, et al. International consensus report on the investigation and management of primary immune thrombocytopenia. Blood. 2010; 115:168-186.

48. PEERSCHKE EI, YIN W, GHEBREHIWET B. Complement activation on platelets: implications for vascular inflammation and thrombosis. Mol Immunol. 2010; 47(13):2170-2175.

49. NORIS P, KLERSY C, ZECCA M, ARCAINI L, PECCI A, MELAZZINI F, et al. Platelet size distinguishes between inherited macrothrombocytopenias and immune thrombocytopenia. J Thromb Haemost. 2009; 7(12):2131-2136.

50. BARSAM SJ, PSAILA B, FORESTIER M, PAGE LK, SLOANE PA, GEYER JT, et al. Platelet production and platelet destruction: assessing mechanisms of treatment effect in immune thrombocytopenia. Blood. 2011; 117(21):5723-5732.

51. HOUWERZIJL EJ, BLOM NR, VAN DER WANT JJ, ESSELINK MT, KOORNSTRA JJ, SMIT JW, et al. Ultrastructural study shows morphologic features of apoptosis and para-apoptosis in megakaryocytes from patients with idiopathic thrombocytopenic purpura. Blood. 2004; 103(2):500-506.

52. MCMILLAN R. Antiplatelet antibodies in chronic immune thrombocytopenia and their role in platelet destruction and defective platelet production. Hematol Oncol Clin North Am. 2009; 23(6):1163-1175.

53. NURDEN AT, FRESON K, SELIGSOHN U. Inherited platelet disorders Haemophilia. 2012; 18(Suppl 4):154-60.

54. BALDUINI CL, PECCI A, SAVOIA A. Recent advances in the understanding and management of MYH9-related inherited thrombocytopenias. Br J Haematol. 2011; 154(2):161-174.

55. BERNDT MC, ANDREWS RK. Bernard-Soulier syndrome. Haematologica. 2011; 96(3):355-359.

56. PORTEILJE JEA, WESTENDORP RGJ, KLUIN-NELEMANS HC, BRAND A. Morbidity and mortality in adults with idiopathic thrombocytopenic purpura. Blood. 2001; 97:2549-2554.

57. MAZZUCCONI MG, FAZI P, BERNASCONI S, DE ROSSI G, LEONE G, GUGLIOTTA L, et al. Therapy with high-dose dexamethasone (HD-DXM) in previously untreated patients affected by idiopathic thrombocytopenic purpura: a GIMEMA experience. Blood. 2007; 109:1401-1407.

58. CHENG Y, WONG RS, SOO YO, CHUI CH, LAU FY, CHAN NP, et al. Initial treatment of immune thrombocytopenic purpura with high-dose dexamethasone. N Engl J Med. 2003; 349:831-836.

59. ZAJA F, BACCARANI M, MAZZA P, BOCCHIA M, GUGLIOTTA L, ZACCARIA A, et al. Dexamethasone plus rituximab yields higher sustained response rates than dexamethasone monotherapy in adults with primary immune thrombocytopenia. Blood. 2010; 115(14):2755-2762.

60. BAE SH, RYOO H, LEE WS. High dose dexamethasone vs conventional dose prednisolone for adults with immune thrombocytopenia: a prospective multicenter phase III trial. Blood. 2010; 116.

61. LEONTYEV D, KATSMAN Y, BRANCH DR. Mouse background and IVIG dosage are critical in establishing the role of inhibitory Fcgamma receptor for the amelioration of experimental ITP. Blood. 2012; 119(22):5261-5264.

62. COOPER N. Intravenous immunoglobulin and anti-RhD therapy in the management of immune thrombocytopenia. Hematol Oncol Clin North Am. 2009; 23(6):1317-1327.

63. GAINES AR. Disseminated intravascular coagulation associated with acute hemoglobinemia or hemoglobinuria following $R h(0)(D)$ immune globulin intravenous administration for immune thrombocytopenic purpura. Blood 2005; 106(5):1532-1537. 
64. COOPER N, WOLOWSKI BMR, FODERO EM, NOVOA M, LEBER M, BEER JH, et al. Does treatment with intermittent infusion of intravenous anti-D allow a proportion of adults with recently diagnosed immune thrombocytopenic purpura to avoid splenectomy. Blood. 2002; 99:1922-1927.

65. GEORGE JN, KOJOURI K, PERDUE JJ, VESELY SK. Management of patients with chronic, refractory idiopathic thrombocytopenic purpura. Sem Hematol. 2000; 37:290-298.

66. PSAILA B, BUSSEL JB. Refractory immune thrombocytopenic purpura: current strategies for investigation and management. Br J Haematol. 2008; 143(1):16-26.

67. PATEL VL, MAHEVAS M, LEE SY, STASI R, CUNNINGHAM-RUNDLES S, GODEAU B, et al. Outcomes 5 years after response to rituximab therapy in children and adults with immune thrombocytopenia. Blood. 2012; 119(25):5989-5995.

68. PROVAN D, BUTLER T, EVANGELISTA ML, AMADORI S, NEWLAND AC, STASI R. Activity and safety profile of low-dose rituximab for the treatment of autoimmune cytopenias in adults. Haematologica. 2007; 92(12):1695-1698.

69. STASI R, DEL POETA G, EVANGELISTA ML, COOPER N, AMADORI S. Response to B-cell depleting therapy with rituximab reverts the abnormalities of T-cell subsets in patients with idiopathic thrombocytopenic purpura. Blood 2007; 110:2924-2930.

70. RODEGHIERO F. First-line therapies for immune thrombocytopenic purpura: re-evaluating the need to treat. Eur J Haematol Suppl. 2008; 69:19-26.

71. MIKHAEL J, NORTHRIDGE K, LINDQUIST K, KESSLER C, DEUSON R, DANESE M. Short-term and long-term failure of laparoscopic splenectomy in adult immune thrombocytopenic purpura patients: a systematic review. Am J Hematol. 2009; 84(11):743-748.

72. THOMSEN RW, SCHOONEN WM, FARKAS DK, RIIS A, JACOBSEN J, FRYZEK JP, et al. Risk for hospital contact with infection in patients with splenectomy: a population-based cohort study. Ann Intern Med. 2009;151(8): 546-555.

73. GHANIMA W, GODEAU B, CINES DB, BUSSEL JB. How I treat immune thrombocytopenia: the choice between splenectomy or a medical therapy as a second-line treatment. Blood. 2012; 120(5):960-969.

74. KUTER DJ, RUMMEL M, BOCCIA R, MACIK BG, PABINGER I, SELLESLAG D, et al. Romiplostim or standard of care in patients with immune thrombocytopenia. N Engl J Med. 2010; 363(20):1889-1899.

75. STASI R, BOSWORTH J, RHODES E, SHANNON MS, WILLIS F, GORDON-SMITH EC. Thrombopoietic agents. Blood Rev. 2010; 24(4-5):179-190.

76. KUTER DJ. Romiplostim. Cancer Treat Res. 2011; 157:267-288.

77. KUTER DJ, BUSSEL JB, LYONS RM, PULLARKAT V, GERNSHEIMER TB, SENECAL FM, ET AL. Efficacy of romiplostim in patients with chronic immune thrombocytopenic purpura: a double-blind randomised controlled trial. Lancet. 2008; 371(9610): 395-403.

78. BUSSEL JB, PINHEIRO MP. Eltrombopag. Cancer Treat Res. 2011; 157:289-303.

79. CHENG G, SALEH MN, MARCHER C, VASEY S, MAYER B, AIVADO M, et al. Eltrombopag for management of chronic immune thrombocytopenia (RAISE): a 6-month, randomised, phase 3 study. Lancet. 2011; 377(9763):393-402.

80. SALEH MN, CHENG G, BUSSEL JB, MEYER O, BAILEY CK, ARNING M, et al. Safety and efficacy of extended treatment with Eltrombopag in adults with chronic immune thrombocytopenia: results of the long-term, open-label EXTEND study. Blood. 2013; 121(3):537-45

81. CUKER A, CHIANG EY, CINES DB. Safety of the Thrombopoiesis-stimulating Agents for the Treatment of Immune Thrombocytopenia. Curr Drug Saf. 2010; 5(2):171-181.

82. IMBACH P, CROWTHER M. Thrombopoietin-receptor agonists for primary immune thrombocytopenia. N Engl J Med. 2011; 365(8):734-741.

83. SARPATWARI A, BENNETT D, LOGIE JW, SHUKLA A, BEACH KJ, NEWLAND AC, et al. Thromboembolic events among adult patients with primary immune thrombocytopenia in the United Kingdom General Practice Research Database. Haematologica 2010; 95:1167-1175

84. JANSSENS A, TARANTINO MD, BIRD R. Final results from a multicenter, international, single arm study evaluating the efficacy and safety of Romiplostim in adults with primary immune thrombocytopenia. Blood 2011; 118.

85. BRYNES RK, ORAZI A, VERMA S, BRAINSKY K, BAILEY CK, BAKSHI K. Evaluation of bone marrow reticulin in patients with chronic immune thrombocytopenic purpura (ITP) treated with Eltrombopag-data from the EXTEND study. Blood. $2011 ; 118$.

86. SPAHR JE, RODGERS GM. Treatment of immune-mediated thrombocytopenia purpura with concurrent intravenous immunoglobulin and platelet transfusion: a retrospective review of 40 patients. Am J Hematol. 2008; 83(2):122-125.

87. KOJOURI K, VESELY SK, TERRELL D, GEORGE J. Splenectomy for adult patients with idiopathic thrombocytopenic purpura: a systematic review to assess long-term platelet count responses, prediction of response, and surgical complications. Blood 2004; 104:2623-2634.

88. VESELY SK, ERDUE JJ, RIZVI MA, TERRELL D, GEORGE JN. Management of adult patients with persistent idiopathic thrombocytopenic purpura following splenectomy. Ann Intern Med 2004; 140:112-120.

89. KÜHNE T, BLANCHETTE V, BUCHANAN GR, RAMENGHI U, DONATO H, TAMMINGA RY, et al. Splenectomy in children with idiopathic thrombocytopenic purpura: a prospective study of 134 children from the Intercontinental Childhood ITP Study Group. Pediatr Blood Cancer 2007; 49:829-834.

90. ARNOLD DM, KELTON JG. Current options for the treatment of idiopathic thrombocytopenic purpura. Semin Hematol 2007; 44:S12-S23.

91. GODEAU B, PROVAN D, BUSSEL J. Immune thrombocytopenic purpura in adults. Curr Opin Hematol 2007; 14:535-556.

Received February $20^{\text {th }} 2018$ 